\title{
Prediction of Biogas Production from Co-digestion of Winery Solid Waste and Zebra Manure using modified Gompertz Model (GM) and Logistic Equation (LE)
}

\author{
Wicleffe Musingarimi ${ }^{1}$, Benjamin I. Okeleye ${ }^{1}$, Vincent I. Okudoh ${ }^{1}$ and Seteno K.O. Ntwampe ${ }^{1,2}$
}

\begin{abstract}
The effect of anaerobic co-digestion (ACoD) of winery solid waste (WSW) and Zebra manure (ZM) on the enhancement of biogas production was investigated. Biogas was produced by means of an automated single batch anaerobic digester equipped with a $\mathrm{pH}$ and temperature control. The fermentation of WSW and ZM was conducted as mono anaerobic digestion (MAD) separately as well as ACoD (1WSW: $2 \mathrm{ZM}$ ) at $37^{\circ} \mathrm{C}$ for 30 days. Gas production was predicted using Gompertz Model (GM) and Logistic Equation (LE) and measured through downward displacement of acidified water. Results showed the ACoD (1WSW: 2ZM) method produced higher amount of cumulative biogas $(952.6 \mathrm{~mL})$ as compared to MAD with $30.4 \mathrm{~mL}$ for WSW and $139.9 \mathrm{~mL}$ for $\mathrm{ZM}$ respectively, after 30 days of retention time. A close fit between the predicted and measured biogas values was observed with correlation coefficient of 0.965 and 0.953 for GM and LE model respectively. Hence, the models can be used to predict biogas yields from $\mathrm{ACoD}$ of biodegradable organic waste and ZM. The findings showed the effect of combining WSW with $\mathrm{ZM}$, which could provide essential information and direction for scaling up of biogas production by high-performance ACoD system.

Keywords-Anaerobic co-digestion ( $\mathrm{ACoD})$, biogas, winery solid waste, zebra manure.
\end{abstract}

\section{INTRODUCTION}

Municipal waste materials are bound to proliferate as urbanization increases, posing serious environmental problems and high costs of disposal. Current method of disposal, such as land filling, burning and indiscriminate dumping can be alleviated by biochemical conversion of waste to bioenergy, such as in the biogas production technology. Biogas production by anaerobic digestion is an antique technology which was observed when rotting vegetable matter gave off a flammable gas in ancient Persia [1]. Anaerobic digestion (AD) is the conversion of organic material into biogas by means of a microbial consortium in an environment free of oxygen [2].

Manuscript received August 9, 2019. This work was supported in part by the National Research Foundation of South Africa for the Thuthuka under Grant 99393.

${ }^{1}$ Bioresource Engineering Research Unit (BioERU), Department of Biotechnology, Faculty of Applied Sciences, Cape Peninsula University of Technology, Cape Town, 8000, South Africa; wicleffe@ gmail.com (W.M.); ben_okeleye2005@yahoo.com (B.I.O).

${ }^{2}$ Department of Chemical Engineering, Faculty of Engineering and the Built Environment, Cape Peninsula University of Technology, PO Box 1906, Bellville 7535, South Africa; NtwampeS@cput.ac.za (S.K.O.N.).
Biogas mainly consists of methane $(50-65 \%)$, carbon dioxide $(30-45 \%)$, nitrogen $(0-3 \%)$, hydrogen $(0-1 \%)$ and hydrogen sulphide $(0-1 \%)[3,4]$. Current depletion of fossil fuels and its adverse environmental effect has recently led to an increasing trend of alternative energy security research including biofuels, with a focus on improving its economic viability [5]. However, with so many substrate mixtures to produce biogas such as municipal waste, sewage, manure, green waste or food waste, simulation models are necessary in order to optimize biogas plants efficiency [6]. In sewage treatment, biogas production has been observed to have the advantages of reducing the amount of sludge for disposal, kill most of the pathogens initially present and reducing the bad odour linked to the remaining putrescible substance in the sludge [7]. AD for biogas production is a complex process that needs strict conditions to operate, and also depends on coordination of microbial activity responsible for converting organic matter into biogas [8]. Studies have reported the use of various agro-waste materials containing potential chemical constituents in co-digestion with animal waste to produce biogas [9-11] as presented in Table I.

TABLE I: CHEMICAL CONSTITUENTS OF WINERY SOLID WASTE

\begin{tabular}{|c|c|c|c|c|c|}
\hline Parameter & Unit & $\begin{array}{c}\text { Food } \\
\text { waste } \\
{[10]}\end{array}$ & $\begin{array}{c}\text { Winery } \\
\text { solid } \\
\text { waste } \\
\text { (This } \\
\text { study) }\end{array}$ & $\begin{array}{c}\text { Cow } \\
\text { Manure } \\
{[10]}\end{array}$ & $\begin{array}{c}\text { Zebra } \\
\text { manure } \\
\text { (This } \\
\text { study) }\end{array}$ \\
\hline Total solids (TS) & $\%$ & 18.5 & 17.8 & 16.3 & 25.2 \\
\hline Volatile solids (VS) & $\% \mathrm{TS}$ & 17.0 & 82 & 13.2 & 71 \\
\hline Hydrogen & $\%$ & - & 6.47 & - & 4.53 \\
\hline Calcium & $\%$ & 0.03 & 0.68 & 2.27 & 0.77 \\
\hline Iron & ppm & 100 & 300 , & 150 & 3600 \\
\hline Potassium & $\%$ & 2.3 & 1.93 & 1.27 & 1.28 \\
\hline Magnesium & $\%$ & 0.16 & 0.19 & 4.99 & 0.24 \\
\hline Manganese & ppm & 110 & - & 950 & 300 \\
\hline Sodium & $\%$ & 3.45 & 0.11 & 1.44 & 0.25 \\
\hline Zinc & ppm & 160 & - & 250 & 200 \\
\hline Carbon & & 46.5 & 46.49 & 26.7 & 32.83 \\
\hline Nitrogen & & 2.2 & 1.92 & 5.1 & 1.5 \\
\hline Carbon: Nitrogen & & 21.1 & 24.21 & 5.2 & 21.89 \\
\hline
\end{tabular}


Winery waste (wastes generated from wine production) contains a high concentration of organic compounds especially organic acids (malic, propionic, acetic and tartaric), polyphenols alcohols and esters. The main wastes from a winery are grape stalks, pomace, lees, and stillage as well as wastewater sludge. Grape stalk contain high amount of fibres (lignin and cellulose) as well as a high proportion of nutritive mineral elements such as nitrogen and potassium [12-14]. Winery wastewater comes from cleaning operations of some spilled grape juice and wine as well as the cleaning of tanks, floors and equipment $[12,14]$. Inorganic compounds present are mainly pottasium $(\mathrm{K})$, calcium $(\mathrm{Ca})$, Iron $(\mathrm{Fe})$, magnesium $(\mathrm{Mg})$ and others (See Table I). Approximately 1.3 to $1.5 \mathrm{~kg}$ of residue per litre of wine is produced [12], and almost 20 million tons of wastes generated from wine production with several potential biological activities are thrown away every year worldwide [13]. The major environmental concern of this waste is the build-up of inorganic material in the soil [14].

Zebras (Equus quagga burchelii) are wild herbivores also called African equids (horse family) with distinct stripes. They eat mainly grass but sometimes eat leaves, shrubs, twigs, herbs and bark. Their digestive system allows them to eat food with minimal nutritional value than other herbivores. Zebra's dropping have been found to contain clostridium bacteria that can convert cellulose to butanol. Zebra manure (ZM) is analogous to horse manure, hence it contains high concentration of lignocelluloses and is heterogeneous in composition, size and structure as well as the ability to degrade easily by enzymes or bacteria. ZM is rich in nitrogen, phosphorus and pottasium (Table I) than cow and horse manure, with abundance organic waste and little shear stress for non-mixing reactor helping to keep the microbial consortia [9-11, 15].

Effective biogas production requires selection of a suitable digester technique together with appropriate design. Digester structures depending on the condition of the process selected may be; batch or continuous, one or two phase, dry or wet mode and mesophilic or thermophilic. Other developments in bioreactor technology to improve and optimize biogas production operation conditions include upflow anaerobic filter process, upflow anaerobic sludge blanket, and anaerobic fluidized-bed reactor [16-18]. AD is a multistep biochemical process performed by a consortium of diverse symbiotic microorganisms in the fundamental steps of hydrolysis, acidogenesis, acetogenesis and methanogenesis [8]. Biomass contains organic polymers, namely; proteins, carbohydrates and fats which need to be broken down into micro molecules such as sugars, fatty acids and amino acids by hydrolysis [19]. Hydrolysis is a rate limiting, an essential step in $\mathrm{AD}$ of semi-solid waste [20] since cellulose and hemicellulose are crystalline, preventing polysaccharides from enzymatic attack [21-23], hence; pretreatment is indispensable to speed up the sludge or biomass hydrolysis [24,25]. Acidogenesis can be affected by the process design or structure, hydraulic retention time, concentration of the substrate, $\mathrm{pH}$ and temperature [26]. In some cases pretreatment of substrate with dilute acid can enhance acidogenic fermentation [27]. At this stage, bacteria involving in fermentation process create in the reaction vessel an environment that is acidic in nature which they can't tolerate with the release of carbonic acids, shorter volatile fatty acids, $\mathrm{NH}_{3}, \mathrm{H}_{2} \mathrm{~S}, \mathrm{H}_{2}, \mathrm{CO}_{2}$, alcohols and trace amounts of other derivatives [8]. The acetogenic microorganisms catabolize products from acidogenesis to produce acetate, $\mathrm{H}_{2}$ and $\mathrm{CO}_{2}$ as well as other organic acids such as propionic and butyric acid. Acetogenic bacteria that produce $\mathrm{H}_{2}$ are capable of producing acetate in the presence fatty acids [28]. Methanogenesis is the final stage of $\mathrm{AD}$ where methanogenic archaea form methane from products generated through acetogenesis as well as from some intermediate derivatives released during the process of hydrolysis and acidogenesis [29]. Substrates like formate and methanol can also form biomethane through methanogenesis [30].

Besides microbes governing the anaerobic bioconversion process, other important factors which also play a crucial role include, organic loading rate which affects $\mathrm{AD}$, depending on the quantity of substrate used, as well as the quality of microbial community [31]. Biomass yield is subject to whether it is seasonally produced or constantly supplied year round to feed into the $\mathrm{AD}$ vessels. Substrate utilization rate depends on its complexity to be degraded by resident microbial flora. Environmental conditions, such as; operating temperature, $\mathrm{pH}$ are also essential, since some microbes for the AD process are sensitive to environmental stress [32,33]. The modeling of bacteria growth, batch and steady state of processes depends on substrate concentration, the level of substrate degradation and autocatalytic reaction. The cumulative production of biogas with time is described with Gompertz and Logistic equation. It systematically characterizes the basis structure for kinetic of biogas production process simulation [34]. To the best of our knowledge there is no known study on the anaerobic co-digestion (ACoD) of winery solid waste (WSW) and zebra manure (ZM) for biogas production. This study therefore investigated the chemical analysis of winery waste and zebra manure used in the laboratory production of biogas and the effect of $\mathrm{ACoD}$ on biogas production compared to mono anaerobic digestion (MAD). It further predicts the biogas yield using Gompertz Model (GM) and Logistic Equation (LE).

\section{MAterials AND MethodS}

\section{A. Design and Construction of Anaerobic Digester}

An acrylic glass digester with a total capacity of $5 \mathrm{~L}$ and a working volume of $4 \mathrm{~L}$ was commercially purchased from Glass $\mathrm{Chem}^{\circledR}$, Stellenbosch South Africa. The digester was designed for the production of biogas (methane) and used in the Biotechnology and Chemical Engineering Departments, Cape Peninsula University of Technology (Fig. 1A \& B). 


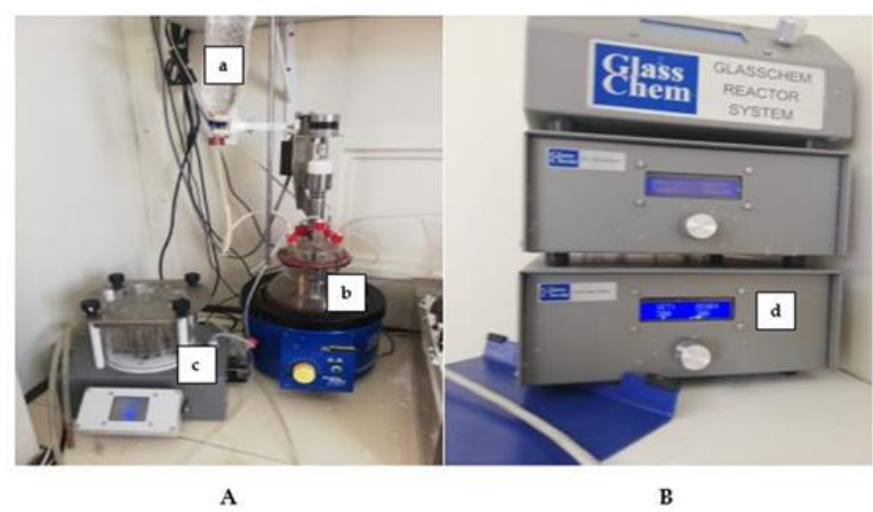

Fig. 1. A, Automatic 5L digester reactor system for the production of biogas. B, Control system. (a) Gas meter, (b) 5L Digester, (c) Auto sampler, (d) System control.

\section{B. Sample Collection and Preparation}

Fresh WSW and ZM were aseptically collected into sterile plastic bags from Agricultural Research Council (ARC) winery farm and a game reserve in Stellenbosch respectively. The samples were transported within 45 minutes to the lab, soaked in warm water and sieved using $4 \mathrm{~mm}$ mesh (200 $\mathrm{mm}$ diameter) prior to use. Samples were mixed in a Conair ${ }^{\mathrm{TM}}$ Waring ${ }^{\mathrm{TM}}$ Laboratory blender (Thermo Fisher Scientific, SA) set at $200 \mathrm{x}$ rpm for 10 minutes. The preparation of seed cultures was done by mixing slurries of WSW and ZM with distilled water at the ratio of $1: 2$ in $1 \mathrm{~L}$ Schott Duran ${ }^{\circledR}$ bottle. An aliquot of $200 \mathrm{~mL}$ of fresh ZM was used as seed culture. Excess fresh samples were stored at $-20^{\circ} \mathrm{C}$ to prevent further biological decomposition and all stock samples were thawed overnight at $4^{\circ} \mathrm{C}$ before use.

\section{Chemical analysis}

Total solids (TS) and volatile solids (VS) of the samples were carried out according to the standard methods for the examination of water and wastewater [35]. The elemental analyses (Ca, Fe, K, Mg, Mn, Na and Zn ) of WSW and ZM was done using a microwave digester (Mars 5 Xpress vessels 2011, USA) and the Inductively Couple Plasma Optical Emission Spectroscopy (ICP - OES) [Thermo Scientific ${ }^{\mathrm{TM}}$ iCAP ${ }^{\mathrm{TM}} 7200$ ICP-OES Analyzer, 2009 USA]. Elemental values with $<100$ $\mathrm{ppb}$ were considered to be below the detection limit of the ICP OES [36]. Total carbon $(\mathrm{C})$ and $(\mathrm{N})$ nitrogen were determined by TruSPEC microanalyser (LECO 2009, UK) and the results were reported on a dry basis with the detection limit of $0.002 \%$ and $0.02 \%$ respectively.

\section{Biogas Production}

Biogas production from ACoD of WSW and ZM was done using a single batch $1 \mathrm{~L}$ Schott Duran ${ }^{\circledR}$ bottle (digester) with a working volume of $750 \mathrm{~mL}$ and later scaled up to $5 \mathrm{~L}$ digester with a working volume of $4 \mathrm{~L}$ equipped with a $\mathrm{pH}$ and temperature control (Fig. 1). The fermentation of WSW and ZM for biogas production was conducted as MAD separately as well as $\mathrm{ACoD}$ (1WSW: $2 \mathrm{ZM}$ ) at $37^{\circ} \mathrm{C}$ for 30 days. Samples were purged with nitrogen before set up to create anaerobic conditions. Volume of biogas produced in the batch digester was measured by the downward displacement of water in an inverted measuring cylinder. Biogas produced was measured daily and tested using flame test with the $\mathrm{pH}$, stirring and temperature monitored through an automated probe. Biogas production with ACoD (1WSW: 2ZM) was predicted using Gompertz Model (GM) and Logistic Equation (LE) as shown in Equations 1 and 2 below:

$$
\mathrm{G}(\mathrm{t})=\mathrm{G} 0 * \operatorname{EXP}(-\operatorname{EXP}(((\mu \max * 2.7183) / \mathrm{G} 0) *(\lambda-\mathrm{t})+1))
$$

$$
\mathrm{L}(\mathrm{t})=\mathrm{L} 0 /(1+\mathrm{EXP}(((4 * \mu \max ) / \mathrm{L} 0) *(\lambda-\mathrm{t})+2))
$$

Where, $G(L)$ is the cumulative of the specific biogas production $(\mathrm{mL}), \mathrm{G} 0 / \mathrm{L} 0$ is the biogas production potential $(\mathrm{mL})$ or initial value (starting point), $\mu$ max is the maximum biogas production rate $(\mathrm{mL} /$ day), $\lambda$ is the lag phase period or the minimum time required to produce biogas (day) and $t$ is the cumulative time for biogas production (days).

\section{RESULTS AND DISCUSSION}

\section{A. Chemical Analysis of the Biomass}

Fig. 2 shows the metal elements of WSW and ZM with $\mathrm{Na}$ and $\mathrm{K}$ content of $0.11 \%, 1.93 \%$ and $0.25 \%, 1.28 \%$, respectively. The concentrations of $\mathrm{Ca}, \mathrm{Mg}, \mathrm{Mn}$ and $\mathrm{Zn}$ in $\mathrm{ZM}$ were $0.77 \%, 0.24 \%, 300 \mathrm{ppm}$ and $200 \mathrm{ppm}$, respectively, which were higher compared to WSW and was in line with other findings reported [10]. WSW contains a high concentration of malic, tartaric, acetic, esters and polyphenols as well as; $\mathrm{K}, \mathrm{Na}$, $\mathrm{Ca}$ and $\mathrm{Mg}$ [14], which corroborated with our findings.

High Fe (3600ppm) content and high TS (25.2\%) were observed for ZM (Fig. 2). High Fe content has been observed to have a stimulatory effect on anaerobic digestion (AD) [20]. Fe acts as an external electron acceptor during anaerobic respiration, hence; helping the degradation of organic substances in the sediment and subsurface. Strains Acidiphilium cryptum and Shewanella saccharophila have been observed to oxidize glucose completely to $\mathrm{CO}_{2}$ and acetate respectively in the presence of $\mathrm{Fe}[9,10,20]$. Many enzymes and co-enzymes require trace elements for their activation and activity [37, 38]. Trace elements in ZM may play a crucial role in boosting methanogen activity in $\mathrm{AD}$ when used in co-digestion with WSW. Trace elements are lower in WSW and addition of ZM enhanced trace elements concentration in the AD system. The effect of $\mathrm{C} / \mathrm{N}$ ratio on the performance of $\mathrm{AD}$ has been reported and compared to that of operating temperature [39]. The range of $\mathrm{pH}$ values of $6.5-8.5$ with $\mathrm{C} / \mathrm{N}$ ratios of $15-25$ and $25-30$ during the whole digestion is mostly observed [39], which was suitable for methanogenic bacteria and found to reduce the negative effects of ammonium nitrogen and free ammonia at $35^{\circ} \mathrm{C}$ thereby increasing biogas production. Too low $\mathrm{C} / \mathrm{N}$ ratio contains high amounts of ammonia, exceeding amounts necessary for bacterial growth which can lead to AD inhibition. High TS for ZM has been observed to be of benefit because of increase in bacteria and archaea species necessary for AD [40]. However, for this study the TS content was medium; therefore lower requirement of it as a supplement from WSW was needed during AD. High VS is an important parameter in methane 
production as a corresponding increase in methane production was observed with increase in VS depending on the load [33]. Increased loading resulted in decreasing methane production due to intermediate volatile fatty acids (VFA) products which inhibit methanogens [33]. The VS also determines how much residual remain after the $\mathrm{AD}$ process as shown by the pale colour and low density of the digestate.

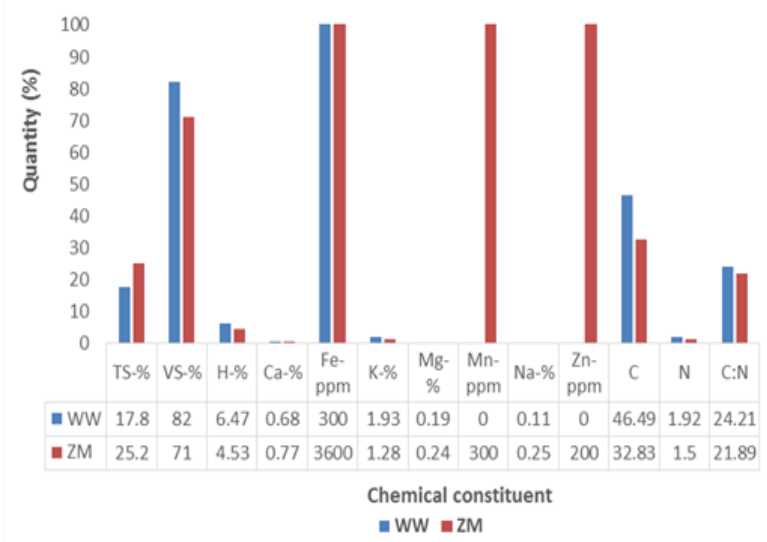

Fig. 2. Chemical analysis of winery waste and zebra manure used as co-digestion biomass for biogas production. FW, food waste; ZM, zebra manure; TS, total solids; VS, volatile solids; $\mathrm{H}$, hydrogen; $\mathrm{Ca}$, calcium; Fe, Iron; K, potassium; Mg, magnesium; Mn, manganese; $\mathrm{Na}$, sodium; Zn, zinc; $\mathrm{C}$, carbon; $\mathrm{N}$, nitrogen; $\mathrm{C}: \mathrm{N}$, carbon: nitrogen ratio.

\section{B. Cumulative Biogas Production}

ACoD [1WSW: 2ZM] method produced 952.6 milliliter $(\mathrm{mL})$ of cumulative biogas after 30 days as compared to MAD of $30.4 \mathrm{~mL} / \mathrm{d}(\mathrm{WSW})$ and $139.9 \mathrm{~mL}(\mathrm{ZM})$ after 30 days of retention time in the digester. Exponential production of biogas was observed for ACoD between 4 to 13 days with $100.2 \mathrm{~mL}$ (day 5) and $783.6 \mathrm{~mL}$ (day 12) of biogas produced. Meanwhile for MAD, $80.7 \mathrm{~mL}$ and $123.5 \mathrm{~mL}(\mathrm{ZM}) ; 24.5 \mathrm{~mL}$ and $25.0 \mathrm{~mL}$ (WSW) were observed on the same days respectively (Fig. 3). ACoD increased biogas production than MAD because of the combination of both ZM and WSW, which is in line with the study conducted by Nielfa et al. [41]. Rumen microorganisms in $\mathrm{ZM}$ are effective inoculum for digesting lignocellulose biomass [23]. Buffering is also introduced by adding ZM which prevents acid accumulation and enhance the supply of macro-nutrients as well as trace elements required by the microflora [23]. Rumen microorganisms were observed to adhere to fibers and it is important for subsequent degradation of lignocellulosic biomass [42]. Grinding reduces the size of the particles and also enhances the distribution of biomass, thereby increasing the surface area and methane yield [43]. However, if maximum AD process is to be achieved, more future developments in understanding important relationships between bacterial and archeal microflora in the biomass is needed. The results obtained from this study showed the synergistic effect of WSW with ZM, which could provide essential information and direction for scaling up of biogas production by high-performance ACoD system in the future.

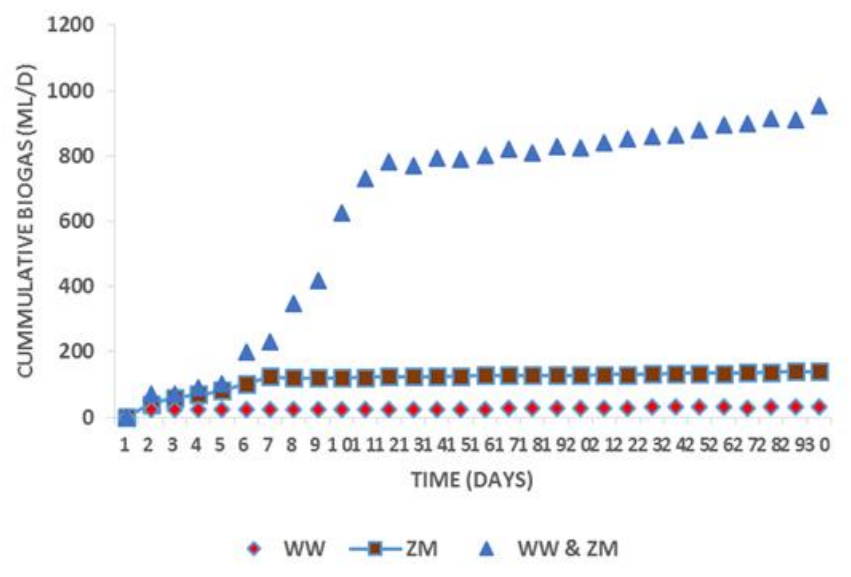

Fig. 3. Comparative cumulative production of biogas

\section{GM and LE Mathematical Model for Biogas Production}

The measured data of the experimental scheme and the predicted responses were shown in Fig. 4 for ACoD (1WSW: 2ZM). The parameters for operation were tested and carefully selected to fit within the range of standard operating conditions and this may justify the experimental and predicted results observed. Maximum specific biogas production rate and lag phase were estimated at 8.108 and 3.034 with standard error of 0.874 and 0.701 respectively using GM as shown in Table II. This is comparable to that of LE model of 8.275 and 3.396 (Table III) biogas production rate and lag phase respectively. The biogas yield depends on the maximum biogas production rate which is the period of digestion at which the bacteria are doubling in population exponentially and this is based on the concentration of volatile solids added and consumed, the density of the effluent and the reaction rate constant, which are all time, volume and substrate or process specific [44]. The maximum cumulative biogas yield at day 30 was $952.6 \mathrm{~mL}$ for experimental measurement, whereas; 0.9519 and $0.9476 \mathrm{~L}$ were observed for LE and GM respectively, hence; the modified equation can be used to predict biogas production. The lag-phase with correlation coefficient of 0.965 and 0.953 for GM and LE model were also observed respectively, thus; GM and LE model can be used to stimulate biogas yields by means co-digestion of biodegradable organic waste and ZM, which is similar to the study conducted by Oyejide et al. [34] with the biogas yield rate also reported to increase linearly as the hydraulic retention time increases, and decreases steadily as the digestion come to completion. The closer the $\mathrm{R}$ value is to 1 , the higher the degree of model fitness to the actual data [45]. The R2 coefficient determined in this study therefore reveals the degree and appropriateness of data for the mathematical model. 


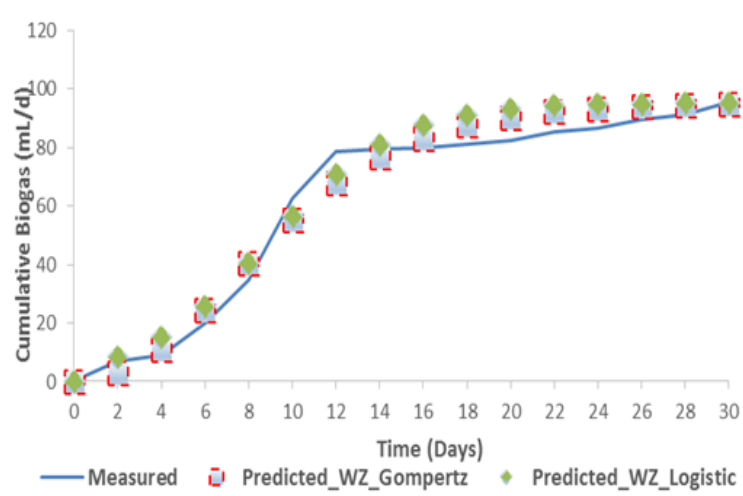

Figure 4. Comparative Gompertz Model (GM) and Logistic Equation (LE) of biogas production

TABLE II: GOMPERTZ MODEL PARAMETER ESTIMATES OF BIOGAS PRODUCED BY TPAC.

\begin{tabular}{|c|c|c|c|c|}
\hline \multirow[b]{2}{*}{ Parameter } & \multirow[b]{2}{*}{ Estimate } & \multirow[b]{2}{*}{ Std. Error } & \multicolumn{2}{|c|}{ 95\% Confidence Interval } \\
\hline & & & Lower Bound & $\begin{array}{l}\text { Upper } \\
\text { Bound }\end{array}$ \\
\hline $\mathrm{R}^{\mathrm{a}}$ & 8.108 & .874 & 6.219 & 9.997 \\
\hline $\mathrm{L}^{\mathrm{b}}$ & 3.034 & $\begin{array}{l}.701 \\
\text { ANOVA }^{c}\end{array}$ & 1.520 & 4.547 \\
\hline \multicolumn{2}{|c|}{ Source } & Sum of Squares & df & $\begin{array}{c}\text { Mean } \\
\text { Squares }\end{array}$ \\
\hline \multicolumn{2}{|c|}{ Regression } & 77550.541 & 2 & 38775.271 \\
\hline \multicolumn{2}{|c|}{ Residual } & 474.502 & 13 & 36.500 \\
\hline \multicolumn{2}{|c|}{ Uncorrected Total } & 78025.044 & 15 & \\
\hline \multicolumn{2}{|c|}{ Corrected Total } & 13713.207 & 14 & \\
\hline
\end{tabular}

${ }^{\mathrm{a}} \mathrm{R}$, Maximum specific biogas production rate.

${ }^{\mathrm{b}} \mathrm{L}$, Lag phase.

${ }^{c} \mathrm{R}$ squared $=1-($ Residual Sum of Squares $) /($ Corrected Sum of Squares $)=$ .965

TABLE III: LOGISTIC EQUATION PARAMETER ESTIMATES OF BIOGAS PRODUCED BY TPAC.

\begin{tabular}{|c|c|c|c|c|}
\hline \multirow[b]{3}{*}{ Parameter } & \multirow[b]{3}{*}{ Estimate } & \multicolumn{3}{|c|}{ 95\% Confidence Interval } \\
\hline & & & & Upper \\
\hline & & Std. Error & Lower Bound & Bound \\
\hline $\mathrm{R}^{\mathrm{a}}$ & 8.275 & 1.150 & 5.791 & 10.760 \\
\hline $\mathrm{L}^{\mathrm{b}}$ & 3.396 & .922 & 1.404 & 5.388 \\
\hline \multirow{2}{*}{\multicolumn{2}{|c|}{ Source }} & ANOVA $^{c}$ & & \\
\hline & & Sum of Squares & df & $\begin{array}{c}\text { Mean } \\
\text { Squares }\end{array}$ \\
\hline \multicolumn{2}{|c|}{ Regression } & 77375.401 & 2 & 38687.700 \\
\hline \multicolumn{2}{|c|}{ Residual } & 649.643 & 13 & 49.973 \\
\hline \multicolumn{2}{|c|}{ Uncorrected Total } & 78025.044 & 15 & \\
\hline \multicolumn{2}{|c|}{ Corrected Total } & 13713.207 & 14 & \\
\hline
\end{tabular}

${ }^{\mathrm{a}} \mathrm{R}$, Maximum specific biogas production rate.

${ }^{\mathrm{b}} \mathrm{L}, \mathrm{Lag}$ phase.

${ }^{\mathrm{c}} \mathrm{R}$ squared $=1-($ Residual Sum of Squares $) /($ Corrected Sum of Squares $)=$ .953 .

\section{CONCLUSION}

Winery waste and Zebra manure are good source of biomass and inoculum for biogas production as chemical analysis of total solids (TS) detected was $17.8 \%$ and $25.2 \%$, while volatile solids (VS) of $82 \%$ and $71 \%$ were recorded for WSW and ZM respectively. Carbon-nitrogen ratio $(\mathrm{C} / \mathrm{N})$ of 24.21 (WSW) and 21.89 (ZM) with 300ppm (WSW) and 3600ppm (ZM) of Iron
$(\mathrm{Fe})$ were observed. High $\mathrm{Fe}$ (3600ppm) content of ZM has a stimulatory effect on anaerobic digestion (AD); hence, enhancing the degradation of the constituents of WSW. ACoD [1WSW: 2ZM] method produced $952.6 \mathrm{~mL}$ of cumulative biogas as compared to MAD of $30.4 \mathrm{~mL}$ (WSW) and $139.9 \mathrm{~mL}$ (ZM) after 30 days of digestion. The modified equation used to predict biogas production showed correlation coefficient of 0.965 and 0.953 for GM and LE model respectively, which can be used to stimulate or optimize biogas yields.

\section{ACKNOWLEDGMENT}

We are grateful to Mrs Mmabatho Mobo and Mr Micheal Tobin of the Department of Biotechnology for their technical assistant.

\section{REFERENCES}

[1] O. Chasnyk, G. Sołowski, and O Shkarupa, "Historical, technical and economic aspects of biogas development: Case of Poland and Ukraine," Renew. Sust. Ener. Rev., vol. 52, pp. 227-239, Jul. 2015. https://doi.org/10.1016/j.rser.2015.07.122

[2] K. C. Surendra, D. Takara, A. G. Hashimoto, and S. K. Khanal, "Biogas as a sustainable energy source for developing countries: Opportunities and challenges," Renew. Sust. Ener. Rev., vol. 31, pp. 846-859, Jan. 2014. https://doi.org/10.1016/j.rser.2013.12.015

[3] V. N. Gunaseelan, "Anaerobic digestion of biomass for methane production: A review," Biom. Bioener. vol. 13, no. 1, pp. 83-114. Mar. 1997.

https://doi.org/10.1016/S0961-9534(97)00020-2

[4] A. J. Ward, P. J. Hobbs, P. J. Holliman, and D. L. Jones, "Optimization of the anaerobic digestion of agricultural resources," Bioresour. Technol., vol. 99, no. 17, pp. 7928-7940, Nov. 2008. https://doi.org/10.1016/j.biortech.2008.02.044

[5] S. K. Karmee, "Liquid biofuels from food waste: Current trends, prospect and limitation," Renew. Sust. Ener. Rev., vol. 53, pp. 945-953, Jan. 2016.

https://doi.org/10.1016/j.rser.2015.09.041

[6] M. Zaefferer, D. Gaida, and T. Bartz-Beielstein, "Multi-fidelity modeling and optimization of biogas plants," Appl. Sof. Comput. vol. 48, pp. 13-28, Nov. 2016.

https://doi.org/10.1016/j.asoc.2016.05.047

[7] L. Appels, J. Baeyens, J. Degrève, and R. Dewil, "Principles and potential of the anaerobic digestion of waste-activated sludge," Progre. Ener. Combust. Sci., vol. 34, no. 6, pp. 755-781, Dec. 2008. https://doi.org/10.1016/j.pecs.2008.06.002

[8] T. Liu, L. Sun, A. Nordberg, and A. Schnürer, "Substrate-induced response in biogas process performance and microbial community relates back to inoculum source, Microorg" vol. 6, no. 80, Aug. 2018. https://doi.org/10.3390/microorganisms6030080

[9] H. M. El-Mashad, and R. Zhang, "Biogas production from co-digestion of dairy manure and food waste," Bioresour. Technol., vol. 101, no. 11, pp. 4021-4028, Jun. 2010. https://doi.org/10.1016/j.biortech.2010.01.027

[10] C. Zhang, G. Xiao, L. Peng, H. Su, and T. Tan, "The anaerobic co-digestion of food waste and cattle manure," Bioresour. Technol., vol. 129, pp. 170-176, Feb. 2013. https://doi.org/10.1016/j.biortech.2012.10.138

[11] J. Ren, X. Yuan, J. Li, X. Ma, Y. Zhao, W. Zhu, X. Wang, and Z. Cui, "Performance and microbial community dynamics in a two-phase anaerobic co-digestion system using cassava dregs and pig manure," Bioresour. Technol., vol. 155, pp. 342-351, Mar. 2014.

https://doi.org/10.1016/j.biortech.2013.12.120

[12] L. A. Ioannou, G. L. Puma, and D. Fatta-Kassinos, "Treatment of winery wastewater by physicochemical, biological and advanced processes: A review," J. Hazardo. Materi. vol. 286, pp. 343-368, Apr. 2015.

https://doi.org/10.1016/j.jhazmat.2014.12.043 
[13] P. S. Melo, A. P. Massarioli, C. Denny, L. F. dos Santos, M. Franchin, G. E. Pereira, T. M. F. D. Vieira, P. L. Rosalen, and S. M. D. Alencar, "Winery by-products: extraction optimization, phenolic composition and cytotoxic evaluation to act as a new source of scavenging of reactive oxygen species," Food Chem., vol. 181, pp. 160-169, Aug. 2015 .

https://doi.org/10.1016/j.foodchem.2015.02.087

[14] K. P. M. Mosse, A. F. Patti, R. J. Smernik, E. W. Christen, and T. R. Cavagnaro, "Physicochemical and microbiological effects of longand short-term winery wastewater application to soils," J. Hazardo. Materi. Vol. 201-202, pp. 219-228, Jan. 2012. https://doi.org/10.1016/j.jhazmat.2011.11.071

[15] M. S. Lynn, Nature Watch: Zebra. Minneapolis, U.S.A.: Lerner publications, $2008, \quad$ pp. $1-48$ https://www.amazon.co.uk/Zebras-Nature-Watch-Lerner-Stone/dp/0 822575116

[16] M. Tabatabaei, R. A. Rahim, N. Abdullah, A. G. Wright, Y. Shirai, K. Sakai, and M. A. Hassan, "Importance of the methanogenic archaea populations in anaerobic wastewater treatments," Proc. Biochem., vol. 45, no. 8, pp. 1214-1225, Aug. 2010. https://doi.org/10.1016/j.procbio.2010.05.017

[17] G. M. Shida, L. T. Sader, E. L. Cavalcante de Amorim, I. K Sakamoto, S. I. Maintinguer, N. K. Saavedra, M. B. A. Varesche, and E. L. Silva, "Performance and composition of bacterial communities in anaerobic fluidized bed reactors for hydrogen production: Effects of organic loading rate and alkalinity," Internat. J. Hydrog. Ener. vol. 37, no. 22, pp. 16925-16934, Nov. 2012.

https://doi.org/10.1016/j.ijhydene.2012.08.140

[18] R. Rajagopal, M. Torrijos, P. Kumar, and I. Mehrotra, "Substrate removal kinetics in high-rate upflow anaerobic filters packed with low-density polyethylene media treating high-strength agro-food wastewaters," J. Environ. Manag. vol. 116, pp. 101-106, Feb. 2013. https://doi.org/10.1016/j.jenvman.2012.11.032

[19] L. Lin, R. Yan, Y. Liu, and W. Jiang, "In-depth investigation of enzymatic hydrolysis of biomass wastes based on three major components: Cellulose, hemicellulose and lignin," Bioresour. Technol., vol. 101, no. 21 pp. 8217-8223, Nov. 2010.

https://doi.org/10.1016/j.biortech.2010.05.084

[20] A. Mudhoo, and S. Kumar, "Effects of heavy metals as stress factors on anaerobic digestion process and biogas production from biomass," Internat. J. Environ. Sci. Technol., vol. 10, no. 6, pp. 1383-1398, Nov. 2013 https://doi.org/10.1007/s13762-012-0167-y

[21] C. Sánchez, "Lignocellulosic residues: Biodegradation and bioconversion by fungi," Biotechnol. Adv., vol. 27, no. 2, pp. 185-194. Mar.-Apr. 2009.

https://doi.org/10.1016/j.biotechadv.2008.11.001

[22] Y. Tamaki, and G. Mazza, "Measurement of structural carbohydrates, lignins, and micro-components of straw and shives: effects of extractives, particle size and crop species," Indust. Cro. Prod., vol. 31, no. 3, pp. 534-541, May 2010.

https://doi.org/10.1016/j.indcrop.2010.02.004

[23] C. Sawatdeenarunat, K. C. Surendra, D. Takara, H. Oechsner, and S. K. Khanal, "Anaerobic digestion of lignocellulosic biomass: Challenges and opportunities," Bioresour. Technol., vol. 178, pp. 178-186, Feb. 2015.

https://doi.org/10.1016/j.biortech.2014.09.103

[24] I. Ferrer, S. Ponsá, F. Vázquez, and X. Font, "Increasing biogas production by thermal $\left(70{ }^{\circ} \mathrm{C}\right)$ sludge pre-treatment prior to thermophilic anaerobic digestion," Biochem. Engineer. J., vol. 42, no. 2, pp. 186-192, Nov. 2008.

https://doi.org/10.1016/j.bej.2008.06.020

[25] L. Yu, M. Bule, J. Ma, Q. Zhao, C. Frear, and S. Chen, "Enhancing volatile fatty acid (VFA) and bio-methane production from lawn grass with pretreatment," Bioresour. Technol., vol. 162, pp. 243-249, Jun. 2014

https://doi.org/10.1016/j.biortech.2014.03.089

[26] E. Jeong, H. Kim, J. Nam, and H. Shin, "Enhancement of bioenergy production and effluent quality by integrating optimized acidification with submerged anaerobic membrane bioreactor," Bioresour. Technol., vol. 101, no. 1, pp. S7-S12, Jan. 2010.

https://doi.org/10.1016/j.biortech.2009.04.064
[27] X. Zhao, L. Wang, X. Lu, and S. Zhang, "Pretreatment of corn stover with diluted acetic acid for enhancement of acidogenic fermentation," Bioresour. Technol., vol. 158, pp. 12-18, Apr. 2014. https://doi.org/10.1016/j.biortech.2014.01.122

[28] H. L. Drake, and S. L. Daniel, "Physiology of the thermophilic acetogen Moorella thermoacetica," Res. Microbiol., vol. 155, no. 10, pp. 869-883, Dec. 2004.

https://doi.org/10.1016/j.resmic.2004.10.002

[29] S. G. Shin, S. Yoo, K. Hwang, M. Song, W. Kim, G. Han, and S. Hwang, "Dynamics of transitional acidogenic community along with methanogenic population during anaerobic digestion of swine wastewater," Proc. Biochem., vol. 46, no. 8, pp. 1607-1613, Aug. 2011. https://doi.org/10.1016/j.procbio.2011.05.001

[30] B. Demirel, and P. Scherer, "Trace element requirements of agricultural biogas digesters during biological conversion of renewable biomass to methane," Biom. Bioener. vol. 35, no. 3, pp. 992-998, Mar. 2011.

https://doi.org/10.1016/j.biombioe.2010.12.022

[31] A. Torkian, A. Eqbali, and S. J. Hashemian, "The effect of organic loading rate on the performance of UASB reactor treating slaughterhouse effluent," Resour. Conservat. Recycl. vol. 40, no. 1, pp. 1-11, Dec. 2003.

https://doi.org/10.1016/S0921-3449(03)00021-1

[32] J. K. Kim, B. R. Oh, Y. N. Chun, and S. W. Kim, "Effects of temperature and hydraulic retention time on anaerobic digestion of food waste," J. Biosci. Bioengineer. vol. 102, no. 4, pp. 328-332, Oct. 2006.

https://doi.org/10.1263/jbb.102.328

[33] F. Raposo, C. J. Banks, I. Siegert, S. Heaven, and R. Borja, "Influence of inoculum to substrate ratio on the biochemical methane potential of maize in batch tests," Proc. Biochem., vol. 41, no. 6, pp. 1444-1450, Jun. 2006.

https://doi.org/10.1016/j.procbio.2006.01.012

[34] J. O. Oyejide, E. K. Orhorhoro, and D. Atadious, "Mathematical modeling of biogas yield from anaerobic co-digestion of organic waste and pig dung," Internat. J. Engineer. Sci. Invent., vol. 7, no. 5, pp. 30-38, May 2018

[35] A. D. Eaton, M. A. H. Franson, L. S. Clesceri, E. W. Rice, and A. E. Greenberg, Standard methods for the examination of water and wastewater, 21st ed.; Washington DC, USA: APHA-AWWA-WEF, 2005, pp. 1-16.

[36] B. B. Popov, S. Najman, V. K. Hristova, M. A. Ahmad, "Inductively coupled plasma-optical emission spectroscopy (icp-oes) approach for the determination of heavy metals, metalloid and trace element in soil and vegetables," Indian Hort. J., vol. 4, no. 2, pp. 98-104, Apr.-Jun. 2004.

[37] J. Böske, B. Wirth, F. Garlipp, J. Mumme, and H. Van den Weghe, "Upflow anaerobic solid-state (UASS) digestion of horse manure: Thermophilic vs. mesophilic performance," Bioresour. Technol., vol. 175 , pp. 8-16, 2015. https://doi.org/10.1016/j.biortech.2014.10.041

[38] D. R. Lovley, and J. D. Coates, "Novel forms of anaerobic respiration of environmental relevance," Curr. Opin. Microbiol. vol. 3, no. 3, pp. 252-256, Jun. 2000. https://doi.org/10.1016/S1369-5274(00)00085-0

[39] X. Wang, X. Lu, F. Li, and G. Yang, "Effects of temperature and Carbon-Nitrogen $(\mathrm{C} / \mathrm{N})$ ratio on the performance of anaerobic co-digestion of dairy manure, chicken manure and rice straw: focusing on ammonia inhibition," Plos One, vol. 9, pp. 1-7, May 2014. https://doi.org/10.1371/journal.pone.0097265

[40] J. Yi, B. Dong, J. Jin, and X. Dai, "Effects of increasing total solids content on anaerobic digestion of food waste under mesophilic conditions: Performance and Microbial characteristics analysis," Plos One, vol. 9, no. 7, pp. 1-10, Jul. 2014. https://doi.org/10.1371/journal.pone.0102548

[41] A. Nielfa, R. Cano, and M. Fdz-Polanco, "Theoretical methane production generated by the co-digestion of organic fraction municipal solid waste and biological sludge," Biotechnol. Repor. vol. 5, pp. 14-21, Mar. 2015.

https://doi.org/10.1016/j.btre.2014.10.005 
[42] Z. Yue, W. Li, and H. Yu, "Application of rumen microorganisms for anaerobic bioconversion of lignocellulosic biomass," Bioresour. Technol., vol. 128, pp. 738-744, Jan. 2013.

https://doi.org/10.1016/j.biortech.2012.11.073

[43] L. Yang, F. Xu, X. Ge, and Y. Li, "Challenges and strategies for solid-state anaerobic digestion of lignocellulosic biomass," Renew. Sust. Ener. Rev., vol. 44, pp. 824-834, Apr. 2015. https://doi.org/10.1016/j.rser.2015.01.002

[44] P. Mahnert, and B. Linke, "Kinetic study of biogas production from energy crops and animal waste slurry: Effect of organic loading rate and reactor size," Environ. Technol., vol. 30, no. 1, pp. 93-99, Jan. 2009.

https://doi.org/10.1080/09593330802246640

[45] M. G. Moghaddam, F. B. H. Ahmad, M. Basri, and M. B. A. Rahman, "Artificial neural network modeling studies to predict the yield of enzymatic synthesis of betulinic acid ester," Electron. J. Biotechnol., vol. 13 , no. 3, pp. 3-4, May, 2010.

https://doi.org/10.2225/vol13-issue3-fulltext-9

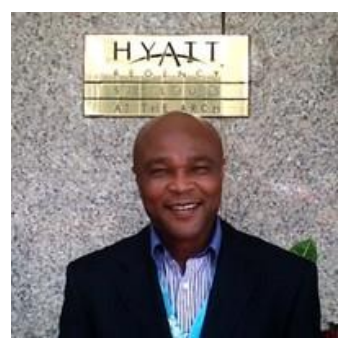

Dr. Vincent I. Okudoh completed his MSc and $\mathrm{PhD}$ in Industrial Microbiology at the University of KwaZulu-Natal (UKZN), South Africa in 2011. Up till 2013, he was a Postdoctoral Research Fellow and a member of the African Energy, Food and Water Research (AEFWR) group under Prof Cristina Trois where he initiated a study on the quantification of cassava biomass as potential feedstock for biogas production. He joined the

Cape Peninsula University of Technology (CPUT) as a Lecturer in 2013 and currently a Senior Lecturer in the Department of Biotechnology. He is a co-principal investigator with the Bio-resource Engineering Research Group (BioERG) in the Department. He has published many articles in top-rated peer-reviewed journals and conference proceedings. He has a certificate in anaerobic digestion from Cranfield University, UK and currently has his own Waste2Energy Laboratory at CPUT. 